\title{
Response and Coping Measures of Various Countries to Attenuate the Spread of Covid-19
}

\author{
AlifyaAltaf \\ Medical Intern, Department of Community Medicine, Jawaharlal Nehru Medical College, DattaMeghe Institute \\ of Medical Sciences (DU), Sawangi (Meghe), Wardha, Maharashtra, Pincode-442001, India \\ Email: -alifya.altaf.306@gmail.com
}

\begin{abstract}
:
The headlines of the year, the coronavirus pandemic is caused by the severe acute respiratory syndrome coronavirus 2 (SARS-CoV-2) also popularly known as covid 19.The news of the outbreak first originated from Wuhan, China in 2019 December.

The modes by which the virus can spread are various, including small droplets released into the surrounding on coughing sneezing or talking. These small droplets land on various surfaces or any object known as fomites and in some cases can also remain in the air as suspended particles infecting many others breathing the same.On touching these contaminated surfaces, most people acquire the virus on their hands which can enter the body when these unwashed hands are bought to face. The virus is capable of spreading thoughout the course of infection or even before one has developed symptoms but it is the most communicable during the first three days of infection. In some cases, patients may remain asymptomatic but can still spread the virus to other healthy contacts.

The virus is manifested in the form of influenza-like symptoms mostly as fever and cough. Some also complain of shortness of breath and loss of sense of taste and smell.Complications can occur like pneumonia with severe shortness of breathandalso acuterespiratorydistresssyndrome.The incubation period, which is the time taken for the symptoms to appear from the day of entry of the virus into ones symptoms is 5 days but can also range from around 2 to 14 days. Vaccines and definitive treatment are still undergoing human trials but none are known to show any proven cure. Primarytreatmentsissymptomaticandsupportivetherapy.
\end{abstract}

Keywords:lockdown,socialdistancing,economy,confirmedcases

\section{Introduction:}

Confusion,fear,anxietyandgriefstriveinever ybylaneandcompoundofallcountries.Ourw orldbattlesagainstaninvisibleenemy,makin geveryefforttosurvivewiththishazardousvir us.Ourtelevisions,socialmedia,newspapers andevenourphonecallconversationsarefloo dedwithdevastatingnewsaboutcorona.Andt hecommonemotionthatweallfacesterror.Th eissuefacedbyeveryoneishowtorespondand manageoneselfnthisstressfulsituationwhich hastakenoverourlivesandcommunitysorapi dly.Countriesallaroundtheworldaretakingth ebestmeasurestohaltthecoronavirusoutbrea kthathasinfected.Innumerablelivesacrossth eglobe.Lockdownwereimplementedbyvari ouscountriesstruckgravelybythepandemict ominimizethespreadofinfection.Limitingon esweeklyoutings,maintainingminimalsocia lcontactandlayingbackatone'sownapartme ntwereagivenasapartofthelockdown.

\section{China:}

TherathofthepandemicoriginatedfromChin a.Inthewakeofthepandemic, theChinesegov ernmenthadtochoosebetweentheirfinancial crisisorthepeople'slives. TheChinese were thepandemicsfirstmajorvictim. By the $22^{\text {nd }}$ of January, the entire number of confirmed cases had spiked to 581 throughout the world, of which 571 were from China and 375 of which were from Huber province.[1].

TheChinesegovernmentbelievedthatitspeo plesliveswerethepriority. Xiao et al. stated that nearly 11 million people were placed in lockdown in Wuhan city [2]. TheChinesegovernmentthenimmediatelyqu arantinedWuhan.Wuhan is popularly known as the capital of Hubeiandthearea most majorly hit by the infectious virus. Theresidentsofthecitywerestrictlypro hibitedfromleavingthecitywhilethebasic 
daily essential needs and all the medical equipment were constantly supplied to the city.The ability to treat the many affected by the pandemic was also significantly increased by the hundreds of medical teams with thousands of medical staff who volunteered from other provinces to help the disease struck city between25Januaryto9March.Within10days ,a fewcovid19specializedhospitals with established5Gsystemshospitalfamiliesand3 000bedswereset uptotreatpeoplewithmildsymptoms.Andasa nadditionalmeasure, allthe 14 millionresiden tsofWuhanwerescreenedtoidentifyallthosei nfected. However, according to a study performed in the Wuhan city there was a major time gap between the appearance of the first few symptoms and the establishment of the final diagnosis was 20 days

[3].Thelockdownmeasureswerethenslowlyf ollowedbytheentirecountry. In a study carried out by Wei et al., it was stated that after 14 February 2020, the virus transmission differed from previous result due to the implementation of universal symptom surveys [4]. Wearingafacemask, avoidingunnecessarytr avel,socialactivitiesandmaintaining thenormalbodytemperatureweremade compulsory for anyone having access to anypublicarea. Additional measures were taken by the Chinese government like delaying activities involving large crowds and also by extending the holiday of educational institutions and work places by further extending leave [5]. Thosepeople withthesymptomswere then transported to the Covid Hospitals of Wuhan in negative pressure ambulances for their further management.Chinesegovernmentstronglyb elievedinnormsliketransparency of information,employingaptanti-

epidemicmeasuresandto make sure that there

isanavailabilityofallnecessarymedicationsa ndequipment.Theresidentshowedstrongded icationinabidingbythenewlyImposedguidel inesandrestrictionsbythegovernment.There
sidentsofWuhancouldbuyalltheirnecessitie sonline.Theydidnothavetosuffer because the new and improved system was immediately and accurately put into effect by the government.Butdespitebeingahealthcarema nufacturingpowerhouse, itcouldnotmeetthe extensivedemandofpersonalprotectionequi pment,disinfectantsanddrugsrequiredbythe peopletoovercomethissituation, theChinese governmenttooktwosteps. Firstly, alltheChi neseproducersweremotivatedto improve thecapacityorchange to manufacturing other items like masks and personal protection equipment which wererequired on a large scale.Asameasuretorelax the questionsofthe large scale personal protection equipment, the government had even passed a decision stating that it would economically cover the losses of all the face mask producers.Secondly,thegovernmentalsopro hibited any sudden hype inpricesthroughstrictregulations. Italsolater setupvarioushotlinestoregister

anyconsumercomplaints and innotime, theChineseproducersweresoonco mpetentenoughtomeetits

peoplesdemandsandeventosupplyothercou ntries.Innotime, theresultswereseen.By2 $3^{\text {rd }}$ March2020therateofdomestictransmission ofviruswasgreatlyreduced.Ithadalsobeguna systematic

continuationofworkandproduction, andatthe sametimetakingallthemeasurestopreventad omesticreboundininfections.Since8April20 20, evenWuhanhascomebacktonormalwith minimaltransmission.

\section{UnitedStates:}

AfterChinatheUSwasamongtheMarjory hit countries by theCOVID19infection.Apublichealthemergencywasa nnouncedon21January2020aftertheconfirm edreportsofthefirstcaseinthecountryarrived. Followingthis,theUS government and embassyhadimmediatelydeclared thehighestlevel4traveladvisory,restrictingit speoplestraveltoChina.

InthemonthofJune

020,UShasthehighestnumberofconfirmedc 
asesreachingapeakofabout2,996,000affecte d. According to the data decoded, as of July 13, 2020 more than 3.3 million U.S residents were diagnosed with Covid-19 of which 135,000 had died [6]. TheUSgovernmenthadannouncedearlymea suresinthemonthofJanuarytoavoidimportsfr om the other infected areas,byprohibiting travel strictly, andalsobyevacuatingallof the US citizens who were present in other countries which were stuck by the corona virus.Onthe $4^{\text {th }}$ March2020,theUnitedStates passeda $\$ 8.3$ bnemergencybilltocombatthes pread.TheUSgovernmentthendeclaredCOV ID-19asanationalemergency in the country on13March2020.Thegovernmentimplemen ted in the

countrysocialdistancingrulesthatbanned more than 10 people from forming a gatheringandalsobeganscreeningatthe majorairports of the country, whichdealtwithmostofthe travelersfromChina.Abanwasimposedforth eentryofanyindividualfromChina or even on those who have traveled through China in the 14 days before they enter the US, excludingthepermanentresidentsandthe remnantvisaholders. TheUSthenpassedabill on13March2020according to which the coronavirus test RT-PCR would be free of cost for the residents of the country.TheCDC establishedtheRTPCRasamodality for diagnosis for testingforthroatswabsofthesuspectedpatient s.Eventhoughthenumberofconfirmedcasesa reonarapidriseinthecountry,theUScontinue stofightagainsttheinvisibleenemy with utmost tenacity.

\section{Brazil:}

Thesecondworsthitcountrybycorona inthemonthJuly2020wasBrazilwitharound 1 ,668,000confirmedcases. Theministryofeco nomy,PauloGuedesannouncedonMarch26, 2020thattheeconomystimuluspackage, byth eEconomic Ministry, financial in charges and banks, both Public and CentralwillbeUS\$150billion,tocompete withtheeconomiccrisisduetoCovid19.Thev olumeofthefundswastosupportthemostvuln erablepopulation,releaseof the laborlawsto some extent

tomaintainthecitizensjobs, which was mainly meant for all the daily age workers and other small scale workers,asanextensionorthepaymentoftaxe sandasafinancialsupporttotheairlineindustr yandvariousothersmallandmediumsizedco mpanies.

\section{India:}

India,beingthesecondmostpopulatedcityint heworld,standsasthethirdmostaffectedcoun trybycoronawith 769,052confirmedcases.In diaonMatch12confirmedits $73^{\text {rd }}$ caseofnovel coronavirus, withKeralareportingthemostnu mberofconfirmedcasesaccordingtotheMini stryofHealthandFamilyWelfare. The initial three cases of the novel corona virus happened on the 30th January and 3rd February in Kerala as they had come back from Wuhan China [7]. Ontheirreturn, theywerequarantinedfora periodof14days. NarendraModi, the prime minister of India announced a nation widejanta curfew for 14 hours[8].Anationwidelockdownwasobservedfrom25thMarc h2020tillthe31stMay2020.Abanwasimpose donpeoplefromsteppingoutoftheirhomesthr oughoutthisperiodandalltheservicesandsho pswereclosedexceptforthepharmacies, hosp itals,banks, groceriesandothernecessaryserv ices.Allthecommercialsendprivateestablish mentswereclosedandalleducational,training andresearchinstitutionsweresuspended.Thi sbanwasalsoapplicableonallplaces ofworshipandnon-

essentialpublicandprivatetransport.In the beginning, it was considered that India had the virus well in control within its boundaries due the implication of lockdown and social distancing [9], but, on the contrary once the carious phases of lockdown had ended, India had a total of 1,90,648 confirmed case among which there were 5407 deaths due to tcovid-19 [10].Amedicalinsuranceofworth500million wasprovidedtoallhealthcareworkersatthefr ontline.Followingthis, theIndiangovernmen tthenarrangedforaspecialAirIndiaflightfor3 24IndiancitizensfromWuhanon $31^{\text {st }}$ January 2020whowerethenquarantinedfor14days.A 
secondbatchwasalsoevacuatedafterthisandt heirhealthconditionwasmonitoredonadaily basis.Thegovernmentalsotookmeasurestoe vacuatethecitizensstrandednran.Afewgover nmentorganizationsincludingtheNationalP harmaceuticalauthority in chargeandDrugscontrollergeneralofIndiaha vebeeninstitutedtomakesurethananadequat e supply of API and also to keep in constraint and corrupted or illegal activities.Fromthe $4^{\text {th }}$ March2020, screening was made compulsory at all airports in the county

thorughout.Thermalscreeningwasmandated at21airportsacrossthecountry. At the same time, screening measures were also established

at around10majorseaportsand60minorseaport s.TheNIV(NationalInstituteofVirology)and around

50otherlaboratoriesundertheIndianCouncil ofMedicalResearch's(ICMR)ViralResearc handDiagnosticsLaboratoriesnetworkhad all the required basic instruments required for testing the citizens presenting with symptoms.TheNIVlab of Punealso was established very early with covid testing and next generation sequencing measures. Also, ICMR advised to conduct ECG (palpitations, chest pain syncope) during the course of prophylaxis [11].TheDGFTlater had established a banon the exportofanypersonalprotectionequipments uchasrespiratorymasksandother equipment of

safetyonthe $31^{\text {st }}$ January2020.Inspiteofitsexc essivelyvastpopulationanddiversity, Indiaco ntinuestofightagainsttheinvisibleviruswith utmostcouragewithallitsmedicalhealthcare workersatitsfrontline. From the industrial point of view, India has grabbed its advantage particularly in the pharma industry, where India depends on $70 \%$ pharmaceutical ingredients [12]. For the purpose of building back the Indian economy the government has even taken an initiative of spending a $\$ 266$ billion package which can improve $4 \%$ of the GDP [13].

\section{Russia:}

AtthefourthplaceliesRussiawitharound700, 000confirmedcasesinJuly.SinceMarch2020 ,theRussianauthoritiestookvariousmeasures toreducetheeffectofCOVID-

19ontheRussianeconomy. Thehealthsystem ofRussiahasimproved a great dealbyimprovingitsdiseasesurveillancesyst emandalsoinitiatedarapidincreaseintestingt oensureanorderlymonitoringofthespreadoft hedisease.A crucial pre-requirement for the present health issue can be deeply connected to the historical legacy of Semashko health system [14].Thenumberoftestspossibleinadayincre asedfromaninitial2,200perdayatthebeginni ngofcrisisto216,500perdayonMay112020.

Soon the passage of foreigners through the Russian-Polish and Russian-Norwegian land borders was suspended [15]. Othermeasurestakenincludewidespreadtest ing, whichwascombinedwithcontacttracing andtheIsolationofpatientswithCOVID19nd esignatedhealthinstitution'sorevenathomes [16.17].Newhospitalswerealsosetupinsome regionswhichevenincludedafewtemporaryh ospitalsforpatientswithmildsymptoms.

\section{Discussion:}

Tostopthediseasefromfurtherspreadisthema joraimofall

countries.Todiagnosethepositivepatsiesthe countriesneedtotest, traceandthenisolatethe infected.Thishasprovedto be highly efficacious in decreasing the spread of the deadly virus, and the results had proved to be even better if these efforts are stared earlier

[1922].Countriesacrosstheglobehaveintroduce dvariouskindsofsocialdistancingmeasuresa ndmonthsoflockdowntocontainthe virus, includingboththe developing and the developed nations [2325](whatsknownas"flatteningthecurve").

Nationsintroducedvarioustestingmeasureso nalargescaletoidentifytheinfected,

thecontactswere immediately quarantinedtopreventthespread, healthfacilitiesweremadeavailableineveryc ornerto all the people, human resources were wisely used in different aspects to 
contain

the

virus

(SouthKorea,China,Singapore).Insomearea s, telemedicineande-

healthhavealsofacilitated

thesuccessofhealthservices.

Establishment of a cooperative environment among the various nations willbeimportant,aiming

tomaximallyutilizealltheavailableresources and utilities, transport, energy and telecommunication modalities. Publicprivatecooperationalongwiththe citizens cooperation smog themselves and with the governments is extremely crucial. Civilian awareness and their voluntary participation in every aspect aiming at containing the virus, stopping the spread and saving the people is very essential.

\section{Conclusion:}

Theworldthatwill emerge from the pandemic will be all countries together leaving behind all its anti nationalistic policies and coming out as more closed off bunch than before. Theimmediateendedofthehouris rapid and systematic nation wide cooperation without which we the krona crises may not end.

Fornow, inmostareasthe, intercountryresponsesintoverypositive.

The governments have not been able to show effective cooperation among each other. Financial and economic crises are not just due to lockdown, but also because of the developed worlds completion for trade and supplies.

Thegovernmentswillsoonberequiredtoreinf orcetheireconomiccondition and achieving this will be next to impossible with a large scale international cooperation and coming as one to win this war against the virus.

ThefirstcrucialelementofaCOVID-

19exitstrategyis testing and identifying every individual suffering from the disease. This will require testing kits and equipment made available to every nook and corner of the nation. Ventilators, masks and access to emergency treatment and equipment is also crucial.

Asecondcomponentofanexitstrategyisa widespreaddiseasesurveillanceandcontrol. MostcountriesincludingIndiaarenowusinga nonlinedatabasesystemtokeepacontinuousc ountofthenumberofpeopleaffectedandbeing treated

recoveredfromthedisease.Howevertheasym ptomaticand undiagnosed populationstillremainunaddressed.

Third,aglobalCOVID-

19exitstrategyaimsatprovidinganappropriat evaccineforthe people.Onthebrighterside, internationalscientificcooperationisincreasi ng

ofprogresstowarddevelopingone.

thepace

Finally,themajoreffectofthispandemicis on the weaker and poorer sections of our society and its upto the governments of different country to effectively manage this crisis and uplift its society from the wrath of the pandemic.

\section{TheCOVID-}

19pandemicputsupanuncalculatable threattothehealthofthenationspeopleaswell asthewealthofevery country.Onlybyputting asidenationalistrhetoricandpromotingstron gerinternationalcooperation, will the governmentsbeabletocomeoutsuccessfulfro mthepandemicandwillbe abletosafeguard its citizens from the deadly virus.

\section{References:}

1. Report of the WHO-China Joint Mission on Coronavirus Disease 2019 (COVID-19). Overview. World Health Organization. Global edition. 28 Feb 2020.

2. Younis I, Longsheng C, Zulfiqar MI, et al. Regional disparities in Preventive measures of COVID-19 pandemic in China. A study from international students' prior knowledge, perception and vulnerabilities. Environmental Science and Pollution Research International. 2020 Oct. DOI: 10.1007/s11356-020-10932-8. 
3. Walach H, Hockertz S. 2020. Wuhan Covid19 data more questions than answers. Toxicology. $2020 \mathrm{Jul} ; 440: 152486$.

4. Wei Y, Wei L, Jiang Y, Shen S, Zhao Y, Hao Y, et al. 2020. Implementation of Clinical Diagnostic Criteria and Universal Symptom Survey Contributed to Lower Magnitude and Faster Resolution of the COVID-19 Epidemic in Wuhan. Engineering (Beijing). 2020 Oct;6(10):1141

5. Zaman TU, Adetunji HA, Mohammed S, Salih EM, Pasha TS, Alsolami M. 2020. A comprehensive review of COVID19 pandemic and community mitigation strategies. Arch Med Health Sci 2020;8:240-6

6. AnusuyaDatta. 2020. Making A Difference: Johns Hopkins COVID Dashboard gets top ESRI award. Blogs. Geospatial World. 14 Aug, 2020.

7. Patrikar S., Poojary D., Basannar D.R., Kunte R. 2020. Projections for novel coronavirus (COVID-19) and evaluation of epidemic response strategies for India. Med. J. Armed Forces India. 2020 Jul;76(3):268. doi: 10.1016/j.mjafi.2020.05.001.

8. 2020. What Is Janata Curfew: Self Isolation by the People, for the People to Prevent Coronavirus. India News.News. The Times of India- Online; 19 March, 2020.

9. Paital B., Das K., Parida S.K. 2020. Inter nation social lockdown versus medical care against COVID-19, a mild environmental insight with special reference to India. Sci. Total Environ. 2020;728:138914. doi: 10.1016/j.scitotenv.2020.138914.

10. Ghosh K, Sengupta N, Manna D, De SK. 2020. Inter-state transmission potential and vulnerability of COVID-19 in
India. Progress in Disaster Science. $2020 \quad$ Oct;7:100114.doi: 10.1016/j.pdisas.2020.100114.

11. MigitaD'Cruz. 2020.The ICMR bulletin on targeted hydroxychloroquine prophylaxis for Covid-19: Need to interpret with caution. Indian Journal of Medical Ethics. Apr. 2020. Vol V, No 2 p. 100-102,. DOI:10.20529/IJME.2020.040

12. Chatterjee P. Indian pharma threatened by COVID-19 shutdowns in China. Lancet (London, England) 2020;395:675. doi: 10.1016/S01406736(20)30459-1.

13. Swati Gupta and VedikaSud. 2020.India's Modi Promises \$266 Billion Toprotect Economy from COVID-19. India stimulus COVID 19. CNN business. CNN.13 May 2020.

14. Reshetnikov V, Arsentyev E, Bolevich S, Timofeyev Y, JakovljeviM. Analysis of the Financing of Russian Health Care over the Past 100 Years. Int J Environ Res Public Health [Internet]. 2019 May;16(10).

15. Order of the Government of the Russian Federation: Introduction of Temporary Ban on Export of Separate Types of Products from the Russian Federation. , 14.03.2020, No.622-p.

16. Khatib, M.N., S. Gaidhane, M. Khatib, M. Ahmed, A. Gaidhane, and Z.Q. Syed. "SARS-CoV and SARS-CoV-2: Similar Viruses with Different Trajectories." WutanHuatanJisuanJishu 16 , no. 5 (2020): 544-48.

17. Nisargandha, M.A., and S. Dadaraoparwe. "Spread of Coronavirus Disease 2019 (COVID-19) during the Lockdown in the Indian Population and Preventive Measures." International Journal of Research 
in Pharmaceutical Sciences 11, no. Special Issue 1 (2020): 328-32. https://doi.org/10.26452/ijrps.v11i SPL1.2721.

18. Quazi, A.A., and M. Patil. "Measures of Preventing Covid-19 Transmission." International Journal of Research in Pharmaceutical Sciences 11, no. Special Issue 1 (2020): 1000-1007. https://doi.org/10.26452/ijrps.v11i SPL1.3405.

19. Adhit, K.K., P. AnjankarAshish, and K. Siddhaarth. "COVID-19: A Review of Its Clinical Features, Effects on Gastrointestinal System and Possibility of Faecal Transmission." International Journal of Research in Pharmaceutical Sciences 11, no. Special Issue 1 (2020): 623-27. https://doi.org/10.26452/ijrps.v11i SPL1.2881.

20. Ingole, S.S., and R. Bhutada. "Transmission of Covid 19 through Eyes - Review Article." International Journal of Research in Pharmaceutical Sciences 11, no. Special Issue 1 (2020): 1008-10. https://doi.org/10.26452/ijrps.v11i SPL1.3406.

21. Juneja, S., S. Dangore-Khasbage, and R.R. Bhowate. "Role of Vitamin $\mathrm{d}$ in Prevention of Corona Virus Infection (Covid-19)." International Journal of Research in Pharmaceutical Sciences 11, no. Special Issue 1 (2020): 407-10. https://doi.org/10.26452/ijrps.v11i SPL1.2737.

22. Manyala, S., and S. Parwe. "Efficacy of Rasayan in the Prevention of Communicable Diseases (Janapadhodhwamsa)." International Journal of Research in Pharmaceutical Sciences 11, no. Special Issue 1 (2020): 1134-38. https://doi.org/10.26452/ijrps.v11i SPL1.3558.
23. Patnaik, K.C., and D. Rajput. "Role of Antioxidant Herbs and Yoga Practices in Prevention of Infectious Diseases with Special Reference to Covid-19 Pandemic." International Journal of Research in Pharmaceutical Sciences 11, no. Special Issue 1 (2020): 317-22. https://doi.org/10.26452/ijrps.v11i SPL1.2719.

24. Rathi, R.B., B.J. Rathi, R.S. Bhutada, D. Dasar, and R. Khatana. "Review on Role of Dhoopan in the Prevention of Airborne Infections (Covid-19)." International Journal of Research in Pharmaceutical Sciences 11, no. Special Issue 1 (2020): 246-52. https://doi.org/10.26452/ijrps.v11i SPL1.2706.

25. Gulrandhe, P., A. Sahu, C. Dandale, W.M. Naqvi, P. Phansopkar, and K. Kumar. "Repercussions of Mass Gathering: Covid-19 Pandemic." International Journal of Research in Pharmaceutical Sciences 11, no. Special Issue 1 (2020): 946-50. https://doi.org/10.26452/ijrps.v11i SPL1.3242. 